\title{
STRATEGI KEPEMIMPINAN KEPALA SEKOLAH DALAM MENGOPTIMALKAN KINERJA GURU
}

\author{
Saude \\ Institut Agama Islam Negeri Palu \\ Email : saude@iainpalu.ac.id \\ Hairuddin Cikka \\ Institut Agama Islam Negeri Palu \\ Email : hairuddincikka@iainpalu.ac.id \\ Zaifullah \\ Institut Agama Islam Negeri Palu \\ Email : zaifullah@iainpalu.ac.id
}

\begin{abstract}
Abstrak
Penelitian ini berkenaan dengan strategi kepemimpinan kepala sekolah dalam mengoptimalkan kinerja guru di SMK Negeri I Biromaru. Maka, uraiannya berdasarkan pada permasalahan bagaimana strategi kepemimpinan kepala sekolah dalam mengoptimalkan kinerja guru di Sekolah Menegah Kejuruan (SMK) Negeri 1 Biromaru?, dengan menggunakan metode penelitian kualitatif, melalui observasi dan wawancara mendalam dan studi dokumentasi. Data yang diperoleh dianalisis dengan teknik reduksi data, penyajian data, verifikasi data, dan penarikan kesimpulan.

Hasil penelitian menunjukkan bahwa kepemimpinan kepala sekolah yang optimal, meningkatkan kualitas Guru SMK Negeri I Biromaru. Usaha ini dilakukan melalui empat program strategi kepemimpinan kepala sekolah, yaitu: (1) pembinaan tanggung jawab guru, yang menghasilkan guru yang bertanggung jawab sebagai pengajar, sebagai pembimbing, dan guru sebagai administrator kelas, (2) program pelaksanaan kegiatan pembelajaran, menghasilkan guru yang bertujuan untuk mengetahui penguasaan materi, ketepatan metode yang digunakan, penguasaan kelas, dan sikap. (3) program pembinaan kedisiplinan guru, yang menghasilkan guru yang disiplin dalam hal efektivitas waktu, dan (4) program pembinaan komitmen guru, yang menghasilkan keaktifan guru dalam mengajar sesuai dengan jadwal yang telah ditentukan.
\end{abstract}

\section{Kata Kunci: Strategi Kepemimpinan, Kinerja Guru}

\section{PENDAHULUAN}

Pendidikan pada hakekatnya merupakan salah satu kebutuhan dasar manusia dalam rangka meningkatkan kualitas sumber daya manusia (SDM) guna pencapaian tingkat kehidupan yang semakin maju dan sejahtera. Undang-Undang Nomor 20 tahun 2003 pasal 1 ayat 1 tentang Sistem Pendidikan Nasional mengamanatkan bahwa pendidikan merupakan usaha sadar dan terencana untuk mewujudkan suasana belajar dan proses pembelajaran agar 
peserta didik secara aktif mengembangkan potensi dirinya untuk memiliki kekuatan spiritual keagamaan, pengendalian diri, kepribadian, kecerdasan, akhlak mulia serta ketrampilan yang dimiliki dirinya, masyarakat, bangsa, dan negara. ${ }^{1}$

Sekolah Menengah Kejuruan adalah bagian dari sistem pendidikan nasional yang merupakan pendidikan menengah yang mempersiapkan peserta didik terutama untuk bekerja dalam bidang tertentu, dapat beradaptasi di lingkungan kerja, dapat melihat peluang kerja dan dapat mengembangkan diri di kemudian hari.

Peran dan kinerja guru menjadi salah satu komponen yang paling penting dan strategis. Kinerja guru sangat penting dalam mewujudkan tujuan pendidikan nasional dan menentukan tinggi rendahnya mutu pendidikan, akan tetapi kinerja guru ini banyak dipengaruhi oleh berbagai faktor baik dari dalam maupun dari luar individu yang bersangkutan.

Upaya untuk menghasilkan guru yang profesional bukanlah tugas yang mudah. Guru harus lebih dinamis dan kreatif dalam mengembangkan proses pembelajaran peserta didik. Guru yang profesional tidak akan terwujud begitu saja tanpa adanya upaya pengembangan kompetensi. Salah satu cara untuk mewujudkan pengembangan kinerja guru adalah melalui pembinaan oleh Kepala Sekolah. Kepala Sekolah sebagai pemimpin pendidikan memiliki tugas dan tanggung jawab dalam membina guru yang berada di sekolah yang dipimpinnya. ${ }^{2}$

Dalam Hadits disebutkan bahwa seorang pemimpin harus bertanggung jawab atas apa yang dipimpinnya. Hadits tersebut berbunyi:

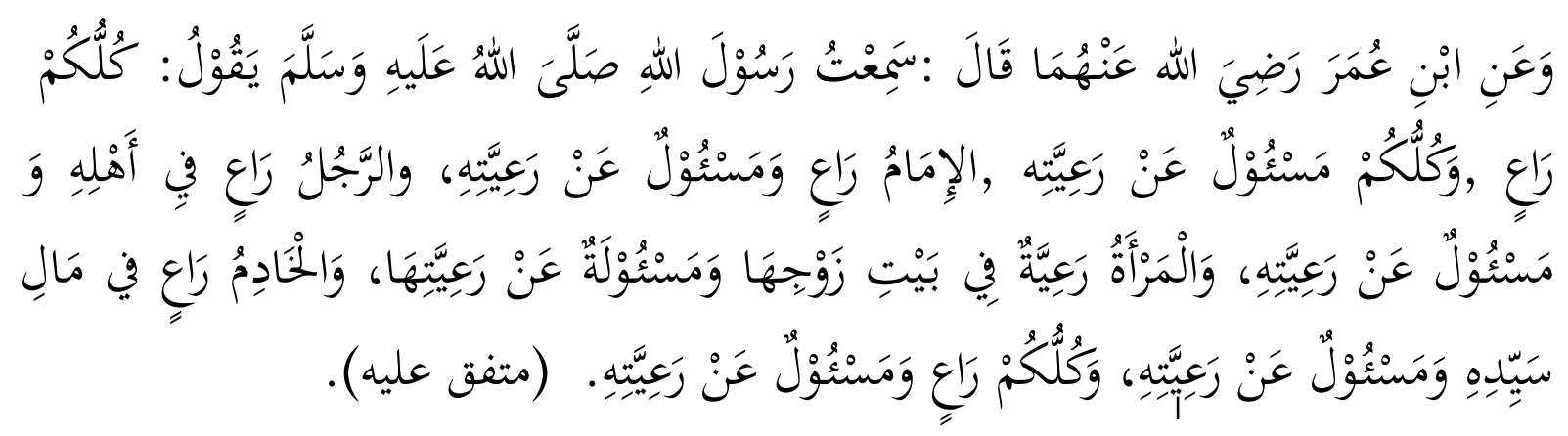

Artinya : "Dari Umar ra berkata: aku pernah mendengar Rasulullah saw bersabda: Kamu semua adalah pemimpin dan kamu semua bertanggung jawab atas rakyat yang dipimpinnya, imam adalah pemimpin dan akan ditanya tentang yrakyat yang dipimpinnya, laki-laki (suami) adalah pemimpin bagi keluarganya dan akan ditanya tentang keluarga yang dipimpinnya, wanita (istri) adalah pemimpin 1 Ayat 1.

${ }^{1}$ Undang-undang Republik Indonesia Nomor 20 tahun 2003 tentang Sistem Pendidikan Nasional Pasal ${ }^{2}$ Martinis Yamin, Standarisasi kinerja guru (Jakarta: GP Press, 2010), 12. 
dirumah suaminya dan ia akan ditanya tentang keluarga yang dipimpinnya, pembantu adalah pemimpin atas harta kekayaan majikannya dan ia akan ditanya tentang kepemimpinannya dan kamu semua adalah pemimpin dan bertanggung jawab atas yang dipimpinnnya."(HR: Bukhari-muslim). ${ }^{3}$

Keberhasilan suatu lembaga pendidikan Sekolah Menengah Kejuruan (SMK) untuk mencapai tujuan yang diinginkan tidak hanya tergantung pada gedung yang megah, media pembelajaran yang lengkap, peralatan praktik yang canggih, kurikulum yang baik, serta sarana pembelajaran lainnya yang dimiliki, melainkan juga tergantung pada sumber daya manusia yang mengelola lembaga pendidikan tersebut. Diantara sumber daya manusia yang sangat dibutuhkan pada kegiatan pembelajaran di SMK adalah guru. Peranan guru dalam kegiatan pembelajaran di Sekolah Menengah Kejuruan tidak hanya dituntut untuk dapat mengajar dan mengembangkan pembelajaran, melainkan harus memiliki memiliki kualifikasi minimum dan sertifikasi sesuai dengan jenjang kewenangan mengajarnya, sehat jasmani dan rohani, serta memiliki kemampuan untuk mewujudkan tujuan pendidikan nasional.

Perkembangan karakteristik program keahlian yang terdapat di SMK cenderung fluktuatif. Perubahan tersebut tentunya akan berpengaruh pada jumlah guru yang ada di SMK. Berdasarkan hasil analisis kebutuhan dan keadaan guru SMK Negeri yang dilakukan oleh Direktorat Dikmenjur menyimpulkan bahwa dari sisi jumlah dan spesialisasi guru ternyata masih mengalami kekurangan, sedangkan dari sisi lain mengalami kelebihan. Kelebihan maupun kekurangan guru SMK tersebut tersebar pada guru program normatif, adaptif, produktif, maupun guru Bimbingan dan Penyuluhan (BP) di semua provinsi Diseluruh Indonesia. ${ }^{4}$

Sekolah Menengah Kejuruan Negeri 1 Biromaru adalah sebuah Sekolah kejuruan yang berada di Kab. Sigi dan merupakan Sekolah favorit yang menawarkan jurusan yang menciptakan lulusan yang siap pakai. Penerapan disiplin yang ketat dalam lingkungan sekolah dan tuntutan guru yang harus optimal dalam mengajar merupakan kunci keberhasilan disekolah ini. Selain itu fasilitas yang cukup memadai dalam pembelajaran. Dalam empat tahun berturut-turut Sekolah ini mendapatkan kelulusan 100\% dan lulusan dari SMK ini telah banyak bekerja diberbagai perusahaan. Dan pada tahun ini mendapatkan

\footnotetext{
${ }^{3}$ Husaini A. Majid Hasyim, Syarah: Riyadus Shalihin. Diterjemahkan Oleh: Mu'ammal Hamidi dan Imron A. Manan (Surabaya: Pt. Bina Ilmu, 1993), 1.

${ }^{4}$ Ibid.,
} 
juara 1 lomba keterampilan sekolah SMK se-Sulawesi Tengah dan akan mewakili Sulawesi Tengah untuk mengikuti lomba yang sama di tingkat nasional pada bulan oktober.

Sekolah Menengah Kejuruan Negeri I Biromaru Menawarkan Berbagai Jurusan yang Sangat Kompetitif. SMK Negeri I Biromaru yang beralamat di JL. Raya Palu-Palolo Kilometer 14 Desa Sidera Kecamatan Sigi Biromaru Kabupaten Sigi Provinsi Sulawesi Tengah. Dan memiliki 5 Jurusan Keahlian yaitu jurusan pertanian (Agribisnis Budidaya tanaman dan Holtirkultura), peternakan, teknik komputer dan jaringan, mekanisasi pertanian, agribisnis perikanan. Dan jurusan-jurusan yang ada ini disesuaikan dengan kultur didaerah Kab. Sigi yang penduduknya mayoritas petani dan peternak Serta pengelola ikan air tawar. Untuk itulah Kab. Sigi sangat membutuhkan para lulusan yang kompeten dibidangnya yang bertujuan untuk memajukan Kab. Sigi pada khususnya dan sulawesi tengah pada umumnya.

Populasi Jumlah SMK Saat ini, sebanyak 73 Sekolah Menengah Kejuruan khususnya Jurusan Pertanian sudah tersebar diseluruh wilayah Indonesia, sementara untuk Sulawesi tengah memiliki 4 sekolah Menegah Kejuruan Jurusan pertanian yang tersebar dibeberapa kabupaten disulawesi tengah dan salah satunya dikabupaten Sigi dan Sekolah Menengah Kejuruan Negeri I Biromaru inilah yang paling maju dan mencetak lulusan-lulusan yang berkualitas dan menjadi SMK Percontohan dan tempat praktek SMK Pertanian yang ada disulawesi tengah.

SMK Negeri I Biromaru memiliki Jumlah peserta didik dan siswi Sebanyak 709 Orang dengan 56 tenaga guru tetap serta 9 tenaga guru lepas, 7 Pegawai atau Staf tetap dan 16 tenaga Honorer. serta ruang kelas yaitu 29 kelas, Laboratorium 3 ruangan, bahasa 3 ruangan, lab computer 3 ruangan, ruang praktek pertanian dan peternakan 6 ruangan, kolam pengembang biakan 9 buah, kebun percontohan $1 \mathrm{Ha}$, lahan pertanian $1 \mathrm{Ha}$, luas lahan keseluruhan $\pm 476.250 \mathrm{M}^{2}$. Gedung Aula 1 ruang, kantin 2 buah, perumahan guru 30 unit, ruang kepala sekolah 1 buah, ruang pertemuan guru I buah, ruang kerja guru 1 buah, ruang wakasek 1 buah, ruang ketua jurusan 1 buah.

SMK Negeri I biromaru memiliki Empat Jurusan Unggulan yakni Bidang Perikanan (Budi Daya Air Tawar), Pertanian (budi dayaTanam Pangan Hotikultura) Peternakan dan Mekanisasi Pertanian yang merupakan jurusan yang disesuaikan dengan keadaan dikabupaten Sigi dan telah banyak mengeluarkan lulusan peserta didik yang kompetitif dibidangnya dan telah bekerja diberbagai perusahaan yang bekerja sama denngan SMK Ngeri 1 Biromaru dan Jurusan-Jurusan ini akan dikembangkan Lagi Kedepannya, dengan ruang belajar dan tenaga guru yang terbatas, saat ini setiap tahunya SMK N I Biromaru hanya mampu menampung 
dan Menerima Peserta didik Baru Sesuai dengan kemampuan kapasitas Fasilitas Sarana dan Prasarana, guna melengkapi pengetahuan dan ilmu peserta didik diberbagai jurusan sekali tiga tahun, SMK Negeri I Biromaru melakukan pengujian kemampuan dengan mengikuti lomba gelar inovasi teknologi tingkat nasional, hal ini bertujuan meningkatkan minat dan wawasan generasi muda dibidang masing-masing, memotivasi generasi muda dibidang teknologi baru, menumbuhkan jiwa kepemimpinan, kemandirian dan daya saing generasi muda serta saling tukar pengalaman antara peserta didik siswi se Indonesia. Pada tanggal 17 s/d 22 September 2012 yang lalu, 10 orang murid SMK Negeri I Biromaru, mengikuti Lomba Inovasi Teknologi Bidang Pertanian tingkat Nasional yang digelar di Mataram, hasilnya juara I Lomba Keterampilan Bidang Pertanian untuk jenis Pencangkokan Kakao dan Juara II di Bidang Pertamanan berhasil disabet sekolah ini. Selain itu, para peserta didik diwajibkan mengikuti pelaksanaan program praktek lapangan ke beberapa Kelompok Tani Central (maju) didaerah Kab. Sigi.

SMK Negeri I Biromaru ini juga sering kali mengirimkan muridnya ke Pulau Jawa Setiap tahunnya dalam studi banding teknologi Bidang Pertanian dan peternakan. Dan program praktek Kerja Industri (PRAKERIN) untuk program Keahlian para Peserta didik yang bertujuan untuk menambah kemampuan para peserta didik sesuai jurusan masingmasing Yang menjadi nilai tambah, Selain itu SMK Negeri I Biromaru memiliki program pasca panen, yakni membekali dengan ketrampilan dalam pengolahan hasil pertanian seperti pengolahan buah nangka menjadi kripik nangka, pebuatan dan pengelolaan pupuk dan lainnya, hal ini diharapkan peserta didik-siswi kita nantinya setelah tamat mampu menciptakan produk sendiri dan membuka lapangan pekerjaan sendiri, bahkan sekolah memiliki program khusus pemberian modal guna mendukung usaha mereka. Dan dari keberhasilan-keberhasilan inilah yang membuat penulis tertarik untuk meneliti di SMK Negeri 1 Biromaru bagaimana strategi kepemimpinan kepala sekolah dalam mengoptimalkan kinerja guru disekolah tersebut.

Berdasarkan latar belakang di atas, yang menjadi pokok permasalahan dalam pembahasan penelitian ini adalah bagaimana Strategi Kepemimpinan Kepala Sekolah Dalam Mengoptimalkan Kinerja di Sekolah Menegah Kejuruan (SMK) Negeri 1 Biromaru?

\section{KAJIAN PUSTAKA}

\section{Teori Kepemimpinan}


Menurut Garry Yuki, "Leadership is the process of influencing other to understand and agree about what needs to be done and how it can be done effectively, and the process of facilitating individual and collective efforts to accomplish the shared objectives" 5 (Kepemimpinan adalah proses mempengaruhi orang lain untuk memahami dan setuju tentang apa yang perlu dikerjakan dan bagaimana tugas itu dapat dilakukan secara efektif, dan proses memfasilitasi usaha individu dan kelompok untuk mencapai tujuan bersama). Menurut Harold Koontz Sebagaimana dikutip Soekarso"Leadership is the art of including subordinates to accomplish their assignment with zeal and confidence" (Kepemimpinan adalah seni mengajak bawahan untuk menyelesaikan pekerjaan-pekerjaan mereka dengan semangat keyakinan). ${ }^{6}$

Reach dan Behling dalam Hughes berpendapat bahwa "Leadership is the process of influncing and organized group toward accomplishing its goals” Kepemimpinan adalah suatu proses dimana individu mempengaruhi kelompok untuk mencapai tujuan organisasi. ${ }^{7}$

Menurut Gibson, ${ }^{8}$ kepemimpinan adalah "suatu usaha yang menggunakan gaya kepemimpinan untuk dapat mempengaruhi dan tidak memaksa dalam memotivasi individu untuk mencapai tujuan" Sedangkan menurut Bass dalam Moedjiono menyatakan bahwa kepemimpinan adalah "usaha individu untuk mengubah tingkah laku orang lain. Bila orang lain benar-benar berubah maka bentuk perubahan tersebut merupakan kepemimpinan yang berhasil""9.

Menurut Soetopo, ${ }^{10}$ kepemimpinan adalah proses mempengaruhi mengarahkan, dan mengkoordinasikan segala kegiatan organisasi atau kelompok untuk mencapai tujuan organisasi dan kelompok" Sedangkan Menurut Thoha, ${ }^{11}$ merumuskan bahwa kepemimpinan adalah kegiatan untuk memepengaruhi perilaku orang lain, atau seni mempengaruhi prilaku manusia baik perorangan maupun kelompok."

${ }^{5}$ Gari Yuki, GLeadership in Organization Saddle River (New Jersey: Prentice Hall,Inc, 2010), 12.

${ }^{6}$ Soekarso Dkk, Teori Kepemimpinan (Jakarta:Mitra Wacana Media, 2011), 7.

${ }^{7}$ Hughes Richard L, Leadership Enhancing the Lessons of Experience (Boston : R. R. Donnelley \& Sons CompanyNorthouse, P.G, 2002), 3.

${ }^{8}$ Gibson, James L, Organization, behavior, struxture and process.Organisasi, perilaku, strukturdan proses: Terjemahan Nunuk Adiarni. (Jakarta: Penerbit Bina rupa Aksara, 1997), 15. 152.

${ }^{9}$ Imam Moedjiono, Kepemimpinan dan Keorganisasian (Yogyakarta : UII Press Yogyakarta, 2002),

${ }^{10}$ Hendyat Soetopo, Perilaku organisasi (Bandung: Remaja Rosda Karya, 2010), 210.

${ }^{11}$ Miftah Thoha, Kepemimpinan dalam Manajemen (Jakarta: PT Raja Grafindo Persada, 2006), 9. 


\section{Pengertian Kepala Sekolah}

Salah satu kekuatan efektif dalam pengelolaan sekolah yang berperan dan bertanggung jawab menghadapi perubahan adalah kepala sekolah. Yaitu kepala sekolah yang mempu memprakarsai pemikiran baru didalam proses interaksi dilingkungan sekolah dengan melakukan perubahan atau penyesuaian tujuan, sasaran, konfigurasi, prosedur, input, proses atau output dari suatu sekolah sesuai dengan tuntutan perkembangan.

Kepala sekolah adalah pemimpin pendidikan yang mempunyai peranan sangat besar dalam meningkatkan mutu pendidikan di sekolah. ${ }^{12}$ meningkatnya mutu pendidikan dengan adanya semangat kerja, kerja sama yang harmonis, minat terhadap perkembangan pendidikan, suasana kerja yang menyenangkan dan perkembangan mutu professional diantara para guru banyak ditentukan oleh kualitas kepala sekolah.

Kepala sekolah merupakan salah satu komponen pendidikan yang paling berperan dalam meningkatkan kualitas pendidikan. Kepala sekolah bertangung jawab atas manajemen pendidikan secara mikro, yang secara langsung berkaitan dengan proses pembelajaran disekolah. Paling tidak kepala sekolah sebagai pemimpin harus mampu mendorong timbulnya kemauan yang kuat dengan penuh semangat dan percaya diri para guru, staf dan peserta didik dalam melaksanakan tugas masing-masing. Karena apabila seorang kepala sekolah ingin berhasil menggerakkan para guru, staf dan para peserta didik berprilaku dalam mencapai tujuan sekolah, maka kepala sekolah harus menghindarkn diri dari sikap dan perbuatan yang sifatnya memaksa atau bertindak keras terhadap para guru, staf dan para peserta didik .

Kepala sekolah adalah salah satu perwujudan kepemimpinan nasional yaitu kepemimpinan pancasila, satu potensi atau kekuatan yang mampu memberdayakan segala daya sumber masyarakat dan lingkungan yang dijiwai oleh sila-sila pancasila mencapai tujuan nasional dalam situasi tertentu. Kepemimpinan dimaksudkan disini adalah bagaimana kepala sekolah mampu mempengaruhi kegiatan seseorang atau sekelompok orang untuk mencapai tujuan dalam situasi tertentu. ${ }^{13}$

\section{METODE}

Jenis penelitian yang penulis gunakan dalam penelitian ini adalah Penelitian Kualitatif. Karena jenis penelitian yang memberikan gambaran atau uraian serta

\footnotetext{
${ }^{12}$ Soewadji Lazaruth, Kepala Sekolah \& Tanggung Jawabnya, (Yogyakarta: Kanisius, 1984), 80.

${ }^{13}$ Agus Dharma, Manajemen Supervisi (Petunjuk Praktis Bagi Para Supervisor), (Jakarta: PT. Raja Grafindo Persada, 2003), 136.
} 
mendeskripsikan fakta empiris dengan kata-kata atau berupa pernyataan lisan tentang bagaimana strategi kepemimpinan kepala sekolah dalam mengoptimalkan kinerja guru di SMK Negeri 1 Biromaru.

Bogdan dan Taylor sebagaimana dikutip oleh Moleong, mendefenisikan penelitian kualitatif adalah sebagai prosedur penelitian yang menghasilkan data deskriptif berupa katakata tertulis atau lisan dari orang-orang dan perilaku yang dapat diambil. Kegiatan pokok dalam penelitian ini adalah mendiskripsikan dan menganalisis secara intensif tentang segala fenomena sosial yang diteliti, yaitu mengenai masalah-masalah yang berkaitan dengan strategi kepemimpinan kepala sekolah dalam mengoptimalkan kinerja guru yang diperoleh secara kualitatif.

Penelitian ini dapat dideskripsikan sebagai penelitian kualitatif berdasarkan ciricirinya yang meliputi :

1. Dilakukan pada kondisi yang alamiah, (sebagai lawannya adalah eksperimen), langsung ke sumber data dan peneliti adalah instrumrn kunci.

2. Lebih bersifat deskriptif. Data yang terkumpul berbentuk kata-kata atau gambar, sehingga tidak menekankan pada angka.

3. Lebih menekankan pada proses daripada produk atau outcome.

4. Analisis data secara induktif.

5. Lebih menekankan makna (data dibalik yang teramati). ${ }^{14}$

Apabila dilihat dari segi tempat penelitian, maka penelitian ini termasuk dalam jenis penelitian lapangan (field research) yang berusaha meneliti atau melakukan studi observasi. Penelitian field research yaitu peneliti berangkat ke lapangan untuk mengadakan pengamatan tentang fenomena dalam suatu keadaan alamiah. ${ }^{15}$

Peneliti memilih jenis penelitian field research karena penelitian ini tentang bagaimana strategi kepemimpinan kepala sekolah dalam mengoptimalkan kinerja guru di SMK Negeri 1 Biromaru yang tidak hanya cukup dengan kajian teori tentang strategi kepemimpianan kepala sekolah dan kinerja guru, tetapi perlu penelitian langsung ke lokasi yang diteliti, yang dikenal dengan istilah observasi dan menggunakan pendekatan yang sistematis yang disebut kualitatif.

Peneliti mengambil objek penelitian di SMK Negeri 1 Biromaru, tepatnya berada di Jalan Raya Palu-Palolo Kilometer 14 Desa Sidera Kecamatan Sigi Biromaru Kabupaten Sigi Provinsi Sulawesi Tengah. Tujuan peneliti mengambil lokasi tersebut untuk mengetahui

\footnotetext{
${ }^{14}$ Sugiyono, Metodologi Penelitian Kombinasi (Mixed Methods), (Bandung: Alfabeta, 2012), 5.

${ }^{15}$ Moleong, Lexi J. Metodologi Penelitian Kualitas. (Bandung: Remaja Rosda Karya, 2008), 2.
} 
strategi kepemimpinan sekolah dalam mengoptimalkan kinerja guru di SMK Negeri 1 Biromaru.

Peneliti tertarik dengan SMK Negeri 1 Biromaru karena, sekolah ini salah satu sekolah kejuruan yang banyak diminati oleh para Siswa karena jurusan yang dimiliki merupakan jurusan agribisnis yang menciptakan lulusan siap pakai. Selain itu selama empat tahun berturut-turut para lulusannya lulus 100\% serta SMK yang ada disulawesi tengah banyak yang melakukan praktek di sekolah ini dikarenakan banyaknya guru produktif yang berkompeten dibidangnya dan SMK Negeri 1 Biromaru Kabupaten Sigi merupakan sekolah percontohan dari SMK yang ada disulawesi tengah karena mampu mencetak siswa yang terampil.

Adapun teknik pengumpulan data yang peneliti gunakan dalam menggali dan mencari data adalah:

\section{Observasi}

Menurut Ridwan, Teknik observasi yaitu melakukan pengamatan secara langsung ke objek penelitian untuk melihat dari dekat kegiatan yang dilakukan. ${ }^{16}$ Senada dengan pernyataan Sutrisno Hadi bahwa dalam pengumpulan data di mana peneliti mengadakan pengamatan secara langsung (tanpa alat) terhadap gejala-gejala subyek yang diselidiki, baik pengamatan itu dilakukan di dalam situasi yang sebenarnya maupun dilakukan di dalam situasi buatan yang khusus diadakan.. ${ }^{17}$ Karena disebut juga sebagai pengamatan, maka kegiatan observasi memusatkan perhatian terhadap sesuatu objek dengan menggunakan indera. Jadi mengobservasi dapat dilakukan melalui penglihatan, penciuman, pendengaran, peraba dan pengecapan.

Observasi digunakan untuk memperoleh data di lapangan dengan alasan untuk mengetahui situasi, menggambarkan keadaan, melukiskan bentuk. Dengan adanya data yang dihasilkan dari observasi tersebut, peneliti dapat mendeskripsikan tentang kinerja guru di SMK Negeri 1 Biromaru, yang dipengaruhi oleh strategi kepemimpinan kepala sekolah di SMK Negeri 1 Biromaru .

\section{Interview}

\footnotetext{
${ }^{16}$ Ridwan, Skala Pengukuran Variabel-variabel Penelitian, (Bandung: Alfabeta, 2011), 30.

${ }^{17}$ Sutrisno Hadi. Metodologi Penelitian, (Yogyakarta: Andi Ooffset, 1989), 162.
} 
Interview sering juga disebut dengan wawancara. Wawancara adalah suatu cara pengumpulan data yang digunakan untuk memperoleh informasi langsung dari sumbernya ${ }^{18}$ Selain itu interview juga berarti alat pengumpulan informasi dengan cara mengajukan sejumlah pertanyaan secara lisan untuk dijawab secara lisan. ${ }^{19}$

Pelaksanaan Dalam melakukan interview, pewawancara harus mampu menciptakan hubungan yang baik sehingga informan bersedia bekerja sama, dan merasa bebas berbicara dan dapat memberikan informasi yang sebenarnya. Tehnik interview yang peneliti gunakan adalah secara terstruktur. Dengan wawancara terstruktur ini responden diberi pertanyaan yang sama, dan pengumpul data mencatatnya. ${ }^{20} \mathrm{Hal}$ ini dimaksudkan agar pembicara dalam wawancara lebih terarah dan fokus pada tujuan yang dimaksud dan menghindari pembicaraan yang terlalu melebar.

Sutrisno Hadi mengemukakan bahwa anggapan yang perlu dipegang oleh peneliti dalam menggunakan metode interview dan juga kusioner (angket) adalah sebagai berikut:

a. Bahwa subyek (Informan) adalah orang yang paling tahu tentang dirinya sendiri.

b. Bahwa apa yang dinyatakan oleh subyek kepada peneliti adalah benar dan dapat dipercaya.

c. Bahwa interpretasi subyek tentang pertanyaan-pertanyaan yang diajukan peneliti kepadanya adalah sama dengan apa yang dimaksud oleh peneliti. ${ }^{21}$

Jadi interview ini dilakukan untuk mendapatkan data-data secara langsung dari personil yang berkaitan dengan penelitian ini adalah wawancara dengan kepala sekolah, wakil kepala sekolah dan guru bidang studi diSMK Negeri 1 Biromaru.

\section{Dokumen}

Teknik dokumen adalah mencari data mengenai hal-hal atau variabel yang baru berupa catatan, transkip, buku, surat kabar, majalah, prasasti, notulen rapat, legger, agenda dan sebagainya. ${ }^{22}$

Metode dokumentasi adalah cara pengumpulan informasi atau data-data melalui pengujian arsip dan dokumen-dokumen. Strategi dokumen juga merupakan teknik pengumpulan data yang ditujukan kepada subyek penelitian. ${ }^{23}$

\footnotetext{
${ }^{18}$ Riduwan, Skala Pengukuran, 29.

${ }^{19}$ S. Margono, Metodologi Penelitian Pendidikan, (Jakarta: Renika Cipta, 1999), 165.

${ }^{20}$ Sugiyono, Metodologi Penelitian, 138.

${ }^{21}$ Ibid, 138.

${ }^{22}$ Suharsini Arikunto, Prosedur Penelitian, 231.
} 
Metode pengumpulan data dengan menggunakan metode dokumen ini dilakukan untuk mendapatkan data tentang keadaan lembaga, yaitu keberadaan kepala sekolah, keadaan guru, keadaan siswa dan keadaan sekolah itu sendiri.

Jadi, metode dokumentasi ini dilakukan untuk mencari dokumen-dokumen resmi tentang sejarah SMK Negeri 1 Biromaru, Visi dan Misi SMK Negeri 1 Biromaru, Struktur Organisasi SMK Negeri 1 Biromaru, Profil Kepala Sekolah SMK Negeri 1 Biromaru data guru, staf dan siswa SMK Negeri 1 Biromaru serta kegiatan proses pembelajaran dan lain sebagainya. Selain itu, dokumentasi yang berupa foto-foto selama proses penelitian berlangsung.

\section{HASIL DAN PEMBAHASAN}

SMK Negeri 1 Biromaru mempunyai visi "mewujudkan tamatan yang beriman dan bertaqwa kepada Tuhan Yang Maha Esa, memiliki kemampuan teknologi, mampu mengisi pasar kerja local nasional dan global, professional, adaptif, serta mampu berwirausaha sesuai bidang keahliannya dan indikator dari visi SMK Negeri 1 Biromaru yaitu :

a. Semua warga sekolah taat menjalankan ajaran agama yang dianutnya.

b. Tamatan mampu menggunakan teknologi sesuai dengan bidang keahliannya.

c. Tamatan dapat diterima sebagai tenaga kerja baik lokal, nasional dan global.

d. Tamatan mampu membuka usaha sesuai dengan kebutuhan dan kondisi dimana tamatan berdomisili.

Selain visi yang telah dikemukakan diatas ada 6 misi yang diupayakan di SMK Negeri 1 Biromaru yang mana misi tersebut selaras dengan tuntutan system pendidikan nasional dan visi sekolah, maka SMK Negeri 1 Biromaru menetapkan misi sebagai berikut :

a. Melaksanakan sholat dzuhur berjamaah bagi yang beragama islam dan bagi agama non muslim menyesuaikan dengan cara beribadah sesuai dengan agama masing-masing.

b. Mengimplementasikan nilai-nilai agama dalam pembelajarannya.

c. Melaksanakan pendidikan sistem ganda (PSG) didunia usaha dan dunia industri yang memiliki dan menggunakan teknologi sesuai dengan bidang keahlian.

d. Menjalin kerjasama dengan dunia usaha dan dunia industri untuk penempatan tenaga sesuai kebutuhan.

${ }^{23}$ Sukandarrumidi, Metodologi Penelitian, (Yogyakarta: Gajah Mada University Press, 2004),100. 
e. Membekali para siswa-siswi dengan pembelajaran yang adaptif dan normatif.

f. Melaksanakan pembelajaran praktik wirausaha sesuai dengan bidang keahlian.

Berdasarkan misi tersebut maka indikator misi tersebut yaitu :

a. Pada waktu sholat dzuhur semua siswa dan guru atau pegawai yang beragama Islam melaksanakan sholat dzuhur berjamaah dimasjid sekolah dan bagi non muslin menyesuaikan.

b. Setiap memulai kegiatan belajar guru mengucapkan salam, kemudian siswa diajak berdoa sebelum dan sesudah belajar.

c. Guru dalam memberikan materi pelajaran dapat mengaitkan materi pelajaran dengan nilai-nilai agama.

d. Terlaksananya kegiatan pendidikan sistem ganda (PSG) dengan menjalin kerjasama dengan dunia usaha dan dunia industri.

e. Terlaksananya pembelajaran adaptif dan normatif sesuai dengan tuntutan kurikulum.

f. Terlaksananya pembelajaran kegiatan kewirausahaan sesuai dengan bidang keahlian masing-masing. ${ }^{24}$

Secara objektif SMK Negeri 1 Biromaru telah memberikan sumbangan yang sangat besar bagi masyarakat Sulawesi Tengah dalam rangka memberikan pelayanan pendidikan melalui visi dan misi tersebut yang nantinya akan menjadi acuan bagi tenaga kependidikan yang akan melaksanakan tugas mulia yang diembannya demi mewujudkan stabilisasi pendidikan yang nantinya mengantarkan lembaga pendidikan tersebut sebagai wadah perwujudan cita-cita pendidikan nasional maupun institusional.

Dalam menjalankan visi misinya kepala sekolah menerapkan berbagai pendekatan dan penanaman nilai sebagai berikut: ${ }^{25}$

1. Pendekatan kemanusiaan

Setiap guru yang belum optimal dalam melakukan tugasnya dalam hal ini kinerjanya saya akan memanggil, berbicara empat mata apa yang menjadi kendala guru tersebut dalam hal menjalankan tugasnya dan kendala tersebut saya akan menjadi bahan evaluasi agar seluruh guru yang mempunyai permasalahan akan dibahas dalam rapat antara saya dan para guru untuk mencarikan solusi demi tercapainya kinerja guru yang efektif.

\section{Pendekatan keagamaan}

\footnotetext{
${ }^{24}$ Dokumen profil SMK Neg. 1 Biromaru diambil pada tanggal, 18 mei 2014

${ }^{25}$ Irman Masungo, Kepala SMKN 1 Biromaru, Wawancara, pada tanggal 14 Mei 2014"
} 
Dalam hal keagamaan saya mendata seluruh guru agar melakukan sholat berjamaah dimasjid pada waktu dzuhur disini saya bisa melihat sejauh mana kemauan guru tersebut dalam hal beribadah

a) Pendekatan kejiwaan

Memahami kemampuan guru tersebut apakah guru cekatan dalam bekerja karena setiap guru mempunyai kejiwaan yang berbeda-beda dan saya sebagai kepala sekolah harus bisa memahami kejiwaan para guru dengan tidak bersifat otoriter dalam pengambilan keputusan agar guru tidak merasa tertekan dengan kebijakan yang saya lakukan

Dalam mengoptimalkan kinerja guru ada dua pendekatan nilai yang saya lakukan

1. Nilai Rasa

Nilai yang menggunakan perasaan dalam hal mengambil kebijakan untuk mengoptimalkan kinerja guru melalui beberapa pendekatan tadi yang artinya apabila guru kurang bekerja secara optimal saya tidak langsung memberikan sanksi akan tetapi melakukan pendekatan secara kekeluargaan dan melakukan bimbingan guru. Inti dari nilai rasa adalah memperlakukan guru sebagai mitra kerja bukan sebagai bawahan.

2. Nilai Rasio

Nilai yang mengukur sejauh mana keberhasilan kinerja guru apakah meningkat atau menurun apa bila meningkat kita tingkatkan lagi apabila menurun kita mencari solusi apa yang menjadi kendala tersebut. Apabila guru melakukan pelanggaran dan saya telah melakukan dengan pendekatan nilai rasa guru tersebut harus dikenakan sanksi sesuai dengan aturan yang berlaku. ${ }^{26}$

Dengan demikian adanya kegiatan-kegiatan ekstrakurikuler yang dilaksanakan di lingkungan SMK Negeri 1 Sigi Biromaru, akan memberikan manfaat timbal balik dan saling menunjang antara kegiatan intrakurikuler dengan ekstrakurikuler dan memupuk serta mengembangkan bakat dan prestasi bahkan mengembangkan ilmu pengatahuan khusunya pengatahuan agama dan meningkatkan iman dan takwa kepada Tuhan Yang Maha Esa;

Strategi kepemimpinan Kepala Sekolah dalam mengoptimalkan kinerja guru di Sekolah Menengah Kejuruan (SMK) Negeri 1 Biromaru yaitu:

\section{Program Pembinaan Tanggung Jawab Guru .}

Hasil penelitian dapat dijelaskan bahwa dalam pembinaan tanggung jawab guru Kepala SMK Negeri 1 Biromaru telah membuat perencanaan berupa program tahunan

\footnotetext{
${ }^{26}$ Irman Masungo, Kepala SMKN 1 Biromaru, Wawancara, pada tanggal 15 Mei 201 4"
} 
dengan baik. Dengan penyusunan program maka memungkinkan kegiatan yang akan dilaksanakan berjalan dengan baik, sehingga dapat mencapai hasil dengan baik pula.

\section{Program Pelaksanaan Kegiatan Pembelajaran.}

Dalam melaksanakan program pengajaran kepala sekolah telah melakukan program penilaian guru kelas secara bertahap, penilaian jangka pendek, jangka menengah dan jangka panjang untuk lima tahun ke depan yang ditekankan pada peningkatan mutu proses pembelajaran. hasil yang diharapkan dari penilaian tersebut meliputi: pemenuhan kebutuhan sarana pembelajaran dan gagasan dalam pengembangan kualitas SMKN 1 Biromaru.

\section{Program pembinaan kedisiplinan guru}

Dari hasil penelitian yang dilakukan memberi gambaran bahwa upaya peningkatan kinerja guru yang dilakukan Kepala Sekolah adalah salah satunya juga dengan menerapkan kedisiplinan guru melalui: (1) pembinaan, (2) pengawasan dan (3) tidakan dalam disiplin. Hal ini dapat di gambarkan bahwa kepala SMK 1 Biromaru membina disiplin guru melalui pengarahan secara tertulis dan tidak tertulis disamping juga mengadakan pengawasan melalui piket harian dan melakukan tindakan bagi yang melanggarnya. Berhubungan dengan masalah itu Kepala sekolah mengatakan: Untuk tegaknya disiplin kami memulainya dengan pengarahan dan himbauan baik melalui rapat maupun melalui teguran secara lisan dan tulisan dan pengawasan terhadap guru-guru yang terlambat terutama hari senin karena adanya upacara bendera

\section{Program pembinaan komitmen guru.}

Bukti penelitian menunjukkan bahwa Kepala Sekolah dalam meningkatkan komitmen guru dengan cara melibatkan guru-guru dalam kegiatan penataran dan melibatkan guru-guru dalam kegiatan MGMP. Dengan demikian dapat digambarkan bahwa upaya kepala sekolah dalam membina komitmen guru adalah dengan melibatkan guru-guru dalam mengikuti penataran-penataran bidang studi yang di pegangnya.

\section{KESIMPULAN}

Kepemimpinan kepala sekolah yang sangat efektif dan Efisien Menghasilkan Guru SMK Negeri I biromaru yang berkualitas melalui 4 program strategi kepemimpinan kepala Sekolah Program Pembinaan Tanggung jawab guru menghasilkan guru yang yang bertanggung jawab sebagai pengajar, sebagai pembimbing, guru sebagai administrator kelas. Program pelaksanaan kegiatan pembelajaran Menghasilkan guru yang bertujuan untuk mengetahui: (1) penguasaan meteri, (2) ketepatan metode yang digunakan, (3) penguasaan 
kelas, (4) sikap. Program pembinaan kedisiplinan guru Menghasilkan guru yang Disiplin dalam hal efektivitas waktu, yang dimaksud dengan efektrivitas waktu adalah penggunaan waktu mengajar secara maksimal dengan hasil yang maksimal, guru wajib membuat perencanaan pengajaran yang tujuannya adalah sebagai pedoman pada saat mengajar dimana dalam perencanaan pengajaran materi yang disiapkan dapat disampaikan secara maksimal dan mampu mencapai beberapa indikator yang telah ditetapkan. Disiplin dalam hal berpakaian, ada ketentuan berpakaian bagi seorang guru. Berpakaian harus sopan dan rapi sesuai dengan kriteria seorang pengajar yang baik. Program Program pembinaan komitmen guru. Menghasilkan keaktifan para guru dalam mengajar sesuai dengan jadwal yang telah ditentukan juga merupakan faktor pendukung terlaksananya dan lancarnya proses belajar mengajar pada SMK Negeri 1 Sigi Biromaru dimana dalam pelaksanaan proses pengajaran yang dilakukan para guru SMK Negeri 1 Sigi Biromaru telah melaksanakan tugasnya dengan penuh tanggung jawab. 


\section{DAFTAR PUSTAKA}

Hadi, Sutrisno. Metodologi Penelitian. Yogyakarta: Andi Ooffset, 1989

Husaini A. Majid Hasyim, Syarah: Riyadus Shalihin. Diterjemahkan Oleh : Mu'amma Hamidi dan Imron A. Manan. Surabaya: Pt. Bina Ilmu, 1993

James L, Gibson. Organization, behavior, struxture and process.Organisasi, perilaku, struktur dan proses: Terjemahan Nunuk Adiarni. Jakarta: Penerbit Bina rupa Aksara, 1997

Lazaruth, Soewadji. Kepala Sekolah \& Tanggung Jawabnya. Yogyakarta: Kanisius, 1984

Margono, S. Metodologi Penelitian Pendidikan. Jakarta: Renika Cipta, 1999

Martinis Yamin, Standarisasi kinerja guru. Jakarta: GP Press, 2010

Moedjiono, Imam. Kepemimpinan dan Keorganisasian. Yogyakarta: UII Press Yogyakarta, 2002

Moleong, Lexi J. Metodologi Penelitian Kualitas. Bandung: Remaja Rosda Karya, 2008

Richard L, Hughes. Leadership Enhancing the Lessons of Experience . Boston : $R . R$. Donnelley \& Sons CompanyNorthouse, P.G, 2002

Ridwan. Skala Pengukuran Variabel-variabel Penelitian. Bandung: Alfabeta, 2011

Soekarso Dkk. Teori Kepemimpinan. Jakarta:Mitra Wacana Media, 2011

Soetopo, Hendyat. Perilaku organisasi. Bandung: Remaja Rosda Karya, 2010

Sugiyono. Metodologi Penelitian Kombinasi (Mixed Methods). Bandung: Alfabeta, 2012

Thoha, Miftah. Kepemimpinan dalam Manajemen. Jakarta: PT Raja Grafindo Persada, 2006.

Undang-undang Republik Indonesia Nomor 20 tahun 2003 tentang Sistem Pendidikan Nasional Pasal 1 Ayat 1.

Yuki, Gari. Leadership in Organization Saddle River. New Jersey: Prentice Hall,Inc, 2010 